\title{
Pituitary Stem Cells During Normal Physiology and Disease
}

\author{
Cynthia L. Andoniadou
}

Summary The homeostatic maintenance and functional modification of tissues require a combination of regulated proliferation and differentiation by somatic stem cells and more committed progenitors. Of relevance to regenerative medicine approaches, the endogenous stimulation of cell types for replenishment of damaged tissues requires an understanding of the signals that promote proliferation and direct appropriate differentiation to specialised cell types. We recently showed that pituitary stem cells expressing the transcription factor SOX2 are able to contribute to the generation of new hormone-producing cells during postnatal life. The signals controlling proliferation in the anterior pituitary are poorly understood and little is known about the influences supporting the choices between proliferation and quiescence among stem cells. The WNT signalling pathway is a major regulator of proliferation and influences stem cells in multiple tissues throughout the body as well as cancer stem cells in tumorigenesis. Forced up-regulation of the WNT pathway specifically in SOX2-positive pituitary stem cells by transgenic approaches in mouse stimulates a transient burst of proliferation, maintaining their uncommitted phenotype. These mutated stem cells subsequently induce tumorigenesis in a non-cell autonomous manner, as they promote proliferation of surrounding cell types through the secretion of paracrine factors. The studies presented here aim to provide insights into pituitary stem cell behaviour and their possible roles during disease states.

"If there were no regeneration there could be no life. If everything regenerated there would be no death. All organisms exist between these two extremes." Richard J. Goss, Principles of Regeneration (1969).

C.L. Andoniadou (四)

Division of Craniofacial Development and Stem Cell Biology, King's College London,

Floor 27 Tower Wing, Guy's Campus, London SE1 9RT, United Kingdom

e-mail: cynthia.andoniadou@kcl.ac.uk 


\section{Introduction}

Over the last few years, compelling evidence has demonstrated the presence of adult somatic stem cells in the murine pituitary gland of mice. In this chapter I will summarise the critical in vitro and in vivo evidence demonstrating the presence and functional properties of these cells. In addition, I will highlight how pituitary stem cells can be involved in tumour formation, as has been shown for stem cell populations of other organs.

The regulation of stem cell populations is of interest to regenerative medicine and cancer therapy approaches. Being able to studying the behaviour of stem cells in their tissue niches can lead to a better understanding of how these behave and how they are regulated. An abnormal expansion or depletion of such populations may contribute to neoplasias or organ failure, respectively. In the case of the pituitary gland, this would manifest as hypopituitarism or pituitary tumours. Recently, we (Andoniadou/Martinez-Barbera labs) and other groups have provided evidence that a long-lived, tissue-specific population of undifferentiated progenitor/ stem cells exists within the anterior pituitary gland. Pituitary stem cells (PSCs) are undifferentiated and are able to generate cells of three main progenitor lineages, characterized by expression of the transcription factors, PIT1 (POU1F1), TPIT (TBX19) and SF1 (NR5A1), the expression of which is necessary for terminal differentiation into hormone-secreting cell types. PIT1-positive progenitors are the major lineage of the anterior pituitary and give rise to somatotrophs expressing growth hormone $(\mathrm{GH})$, lactotrophs expressing prolactin (PRL) and thyrotrophs expressing thyroid stimulating hormone (TSH). Progenitors positive for TPIT give rise to ACTH-expressing adrenocorticotrophs and MSH-expressing melanotrophs (refer to Jacques Drouin 2016 for the transcriptional mechanisms regulating these fate choices). Finally, progenitors expressing SF1 cells give rise to gonadotrophs that express LH or FSH. All of these populations need to be precisely regulated to ensure appropriate homeostasis and adequate response for hormone secretion dependent on physiological demand, a process that is very dynamic throughout life.

To be considered PSCs, the cells need to demonstrate both self-renewal and differentiation in vivo. Initial studies pointing towards PTCs relied on in vitro approaches. These identified that there are cells in the postnatal pituitary gland that have the capacity to expand as colonies in culture, i.e., they have clonogenic capacity, demonstrating self-renewal in vitro. One population was characterized by the uptake of the fluorescent dipeptide AMCA and included cells expressing S100 calcium-binding protein B (S100ß; Lepore et al. 2005), which have been described as folliculostellate cells of the anterior lobe (Vila-Porcile 1972). Cells among this population were able to form adherent colonies in culture. The second population was characterized by marker expression similar to stem cells of other tissues (Scal, Nanog and Oct4) and could form floating spheres (Chen et al. 2005). In later studies, the same research group showed that there was enrichment in this population for the expression of SOX2, SOX9, CD44 and CD133 (Chen et al. 2009). 
Additionally, these cells had active function of ABC transporters, which rendered them capable of effluxing the vital dye Hoechst 33342, leading to a discrete 'side population' during flow cytometry when analysing levels of expression of Hoechst. This is a typical property of many cell types that possess properties of stem or progenitor cells. This side population has since been described for pituitaries of other vertebrates (Chen et al. 2005, 2006; van Rijn et al. 2012). In time, additional markers of cells with this in vitro self-renewal capacity have been put forward to refine the characterisation of PSCs, including Nestin, PROP1, SOX9, GFR $\alpha 2$ and PRX1/2 (Gleiberman et al. 2008; Yoshida et al. 2009; Rizzoti et al. 2013; GarciaLavandeira et al. 2009; Higuchi et al. 2014). In the postnatal rodent gland in vivo, SOX2-positive cells displayed a high degree of overlap with other proposed stem cell markers such as SOX9 (Rizzoti et al. 2013), PROP1 (Yoshida et al. 2009, 2011), and PRX1/2 (Higuchi et al. 2014). We confirmed that SOX2-positive cells did not overlap with differentiation markers but we sought to determine if they were able to give rise to all the differentiated lineages in vivo.

The Lovell-Badge lab reported that floating spheres forming from anterior pituitary cells, were positive for SOX2 (Fauquier et al. 2008), in line with Sox2 expression in the side population (Gremeaux et al. 2012). Our group utilised a knock-in mouse strain expressing enhanced yellow fluorescent protein (EYFP) from the SOX2 locus, allowing identification of SOX2-positive cells (Andoniadou et al. 2012). We isolated SOX2-EYFP-positive and -negative populations separately and plated these under conditions promoting the clonogenic expansion of single cells as adherent colonies. Only cells within the SOX2-positive fraction were capable of colony formation. This was also the case when clonogenic potential was assessed via the generation of floating spheres, as reported by the Lovell-Badge group (Rizzoti 2010). In the adherent cultures, time-lapse imaging of singe cells plated at clonal density confirmed that they gave rise to single colonies that contained multiple EYFP-positive cells, demonstrating self-renewal. Withdrawal of growth factors and prolonged culture in differentiation conditions promoted the expression of markers of the three main pituitary lineages and the expression of differentiation markers, as detected by qPCR (Andoniadou et al. 2012). Interestingly, only a small percentage of SOX $2^{+}$cells were able to form colonies (up to $5 \%$ depending on age), possibly reflecting heterogeneity within this population in terms of their potential; alternatively, the culture requirements allowed for expansion of a restricted subset of cells, where more cell types could have self-renewal capacity. In either case, the requirement for a better-defined combination of markers was clear. To address this issue, we investigated $\mathrm{S} 100 \beta$ as an additional marker of the pituitary stem cell population, as these had a significant overlap with $\mathrm{SOX}_{2}^{+}$cells in vivo (Fauquier et al. 2008; Andoniadou et al. 2013). We purified this population from transgenic mice expressing S100 $\beta$-GFP and found that plating GFP-positive and -negative cells resulted in the enrichment in colonies forming in the GFP-positive compartment. Since this property lies solely within the SOX2-positive cells in our assay (Andoniadou et al. 2013), pituitary stem cells are likely to be enriched within the double-positive population. Double SOX2/S100 $\beta$ are located along the marginal zone, the epithelium lining the remnants of Rathke's pouch lumen, and also in 
the parenchyma of the anterior pituitary, often in groups distributed amongst hormone-secreting cells. We isolated SOX2 cells expressing GFP from these two regions by microdissection, and demonstrated that their in vitro clonogenic potential did not differ between the two locations (Andoniadou et al. 2012). Recent studies from rat have revealed that double-positive $\mathrm{SOX} 2^{+} / \mathrm{S} 100 \beta^{+}$cells may be further refined through in vivo expression of the gene Cxadr, which codes for coxsackievirus and adenovirus receptor (CAR; Chen et al. 2013). Furthermore, expression of E-cadherin and the juxtacrine factor ephrin-B2 reportedly define $\mathrm{SOX}^{+} / \mathrm{S}_{100} \beta^{+} / \mathrm{CAR}^{+}$cells, both in the marginal epithelium and throughout the parenchyma (Chen et al. 2013; Yoshida et al. 2015). Analysing the side population, the Vankelecom group (2010) also reported enrichment in ephrin-B expression in this stem cell-rich compartment; together the data suggested that ephrin-B expression was a hallmark of the population containing PSCs.

\section{The Long-Term Maintenance of the Anterior Pituitary}

Until recently, evidence to support that cells in the pituitary could act as stem cells in vivo was lacking. This evidence has now been provided through genetic tracing of $\mathrm{SOX}^{+}$cells, enabled by the generation of inducible mouse strains expressing CreERT2 under the regulation of the SOX2 promoter, where Cre recombinase is expressed in $\mathrm{SOX}_{2}{ }^{+}$cells but will not be active until the administration of tamoxifen, allowing temporal control of recombinase action (Andoniadou et al. 2013; Arnold et al. 2011). We lineage traced cells expressing Sox2 both during gestation and postnatally (Andoniadou et al. 2013). Similarly, the Lovell-Badge group traced Sox2-expressing and Sox9-expressing cells from embryonic stages (Rizzoti et al. 2013). In all cases, these populations gave rise to all committed progenitor cell types (PIT1, TPIT, SF1) and hormone-secreting cells of the anterior lobe $(\mathrm{GH}$, PRL, TSH, ACTH, LH/FSH). A similar capacity by both $\mathrm{SOX}_{2}^{+}$and $\mathrm{SOX}^{+}$ populations is not surprising since $\operatorname{Sox} 2$ and $\operatorname{Sox} 9$ are co-expressed in the majority of cells from late embryonic stages (Rizzoti et al. 2013). What remains unknown is the extent of heterogeneity within this population. Our assay does not distinguish if a SOX $2^{+}$cell capable of proliferation is multipotent or if there are several distinct oligopotent $\mathrm{SOX}^{+}$sub-populations that collectively cover the different populations. It is, however, able to demonstrate that the population of $\mathrm{SOX}^{+}$cells is long-lived and does not become depleted over time, something that would be expected of a transit-amplifying progenitor population. We activated CreERT2 in postnatal SOX $2^{+}$cells, enabling expression of $R 26 R-E Y F P$, and traced the cells for six months. We assessed the clonogenic potential of $\mathrm{EYFP}^{+}$cells at the end of this period, i.e., the $\mathrm{SOX}_{2}^{+}$cells as well as their derivatives. We flow sorted for EYFP expression and cultured the positive and negative populations under adherent clonogenic conditions. Even after six months, the majority of cells with clonogenic potential (subpopulation of $\mathrm{SOX}^{+}$) resided within the $\mathrm{EYFP}^{+}$fraction, indicating either that SOX2 cells were long-lived, hence persisting long-term after initial 
labeling, or that the pool of $\mathrm{SOX}^{+}$cells was maintained through self-renewal. Importantly, it excluded the possibility that the $\mathrm{SOX}^{+}$pituitary stem cell pool became depleted. Immunofluorescence staining confirmed that, even after a year of tracing following tamoxifen administration, $\mathrm{EYFP}^{+}$cells included $\mathrm{SOX}^{+}$uncommitted cells. The above experiments relied on repeated administration of a high dosage of tamoxifen to ensure that the majority of $\mathrm{SOX}_{2}^{+}$cells were initially labelled. We have further analysed the behaviour of $\mathrm{SOX}^{+}$cells by labelling sparse cells through low dosage administration. The above experiments demonstrate the presence of a long-lived population that retains pituitary stem cell properties throughout normal life. Ongoing efforts focus on the signals that regulate activity of this stem cell compartment and on how the potential of PSCs is maintained during life.

\section{Stem Cells and Pituitary Tumours}

Similar to organ-specific stem cells, analyses of many tumours and cancers have revealed the presence of multipotent cells, which are often thought to drive tumour formation. Many of the properties of 'cancer stem cells' (CSCs) are shared by normal tissue-specific stem cells: slow cycling status, self-renewal and differentiation capacity and even resistance to cytotoxic drugs. For some tumours, it has been shown that normal stem cells are transformed into CSCs when targeted to express oncogenic proteins. For example, intestinal crypt stem cells transform into CSCs when the WNT/ $\beta$-catenin pathway is over-activated (Barker et al. 2009; Zhu et al. 2009). However, progenitor cells or even differentiated cells could give rise to cells fulfilling CSC criteria upon transformation (Valent et al. 2012; Clevers 2011). Several groups have reported the presence of putative CSCs in human pituitary adenomas and from mouse pituitary tumour models (Chen et al. 2014; Xu et al. 2009; Donangelo et al. 2014; Lloyd et al. 2013; Mertens et al. 2015; Orciani et al. 2015; van Rijn et al. 2013; Yunoue et al. 2011; Hosoyama et al. 2010). It remains unknown if CSCs arise from PSCs, although their properties can be similar; for example, both are capable of in vitro self-renewal and differentiation and PSCs are likely to be chemoresistant like CSCs, since PSCs are found within the 'side population' generated by dye efflux, utilising the same transporter properties as chemoresistance (Chen et al. 2009).

In our quest to determine if PSCs are transformed to CSCs following expression of an oncogenic protein, we uncovered a non-cell autonomous role for these cells in tumour formation through the expression of paracrine factors that promote tumour formation by a different cell population. We focused on mutations in CTNNB1, the gene encoding $\beta$-catenin; these mutations have been identified in numerous tumours and in the pituitary, identified in the majority of adamantinomatous craniopharyngioma (ACP) tumours (Buslei et al. 2005). ACPs are aggressive tumours with a tendency to infiltrate the brain, vascular structures and optic tracts (Muller 2014). They represent the most common pituitary tumour type in children and are 
mostly paediatric (Muller 2013). The mutations responsible for the generation of $\mathrm{ACP}$ activate the $\mathrm{WNT} / \beta$-catenin pathway by preventing the degradation of $\beta$-catenin and resulting in its accumulation (Martinez-Barbera 2015). A hallmark of ACP is the presence of small cell clusters that strongly accumulate nucleocytoplasmic $\beta$-catenin, as revealed by immunohistochemistry (Buslei et al. 2007; Hofmann et al. 2006). We expressed this mutation embryonically throughout the developing pituitary primodium, from the early specification of Rathke's pouch using the Hesxl-Cre driver. Hesxl ${ }^{\mathrm{Cre} /+}$; $\mathrm{Ctnnbl}^{\text {lox(ex3)/+ }}$ animals develop tumours very similar to human ACP and contain the hallmark $\beta$-catenin-accumulating cell clusters that activate the WNT/ $\beta$-catenin pathway (Gaston-Massuet et al. 2011). We assessed the mouse tumours for the presence of cells reminiscent of CSCs, which have self-renewal and differentiation properties in vitro, and found an increase of clonogenic cells, up to three times the number compared to normal pituitaries (Gaston-Massuet et al. 2011). These cells expressed markers of stem cells such as Sox2; however, immunofluorescence experiments showed that these predominantly co-localised within the $\beta$-catenin-accumulating clusters. This population of $\mathrm{SOX}^{+}$ cells was expanded compared to normal numbers. In an effort to identify if these cells acted as CSCs in this neoplasm to generate the tumour mass, we pursued a different approach. We expressed the oncogenic $\beta$-catenin specifically in $\mathrm{SOX}_{2}^{+}$ stem cells of postnatal pituitary glands using a mouse model where timing of expression of the oncogenic protein is dependent upon administration of tamoxifen (Sox2 $2^{\text {CreERT2/+}}$; Ctnnbl $1^{\text {lox(ex3)/+ }}$ mouse model). This approach resulted in tumours that were similar to human ACP and the previous embryonic model (Andoniadou et al. 2013). The advantage of this approach was that it allowed us to lineage-trace the fate of the PSCs carrying the oncogenic mutation and determine their contribution to the tumour mass. As done previously for normal PSC lineage tracing, $\mathrm{SOX}^{+}$cells were targeted simultaneously to oncogenic $\beta$-catenin and EYFP, allowing identification of daughter cells derived from the mutated SOX $2^{+}$PSCs (Sox $2^{\text {CreERT2/+} ; ~ C t n n b l ~}{ }^{\operatorname{lox}(e x 3) /+} ; R_{2} 6^{E Y F P /+}$ ). These experiments confirmed that the typical cell clusters derived from $\mathrm{SOX} 2^{+}$cells but, intriguingly, they revealed that the bulk of the tumour mass did not. Therefore, mutated $\mathrm{SOX}^{+} \mathrm{PSCs}$ were not transformed into CSCs by oncogenic $\beta$-catenin; instead, the cell clusters that they generated were found to have the capacity to induce tumours through paracrine signalling (Andoniadou et al. 2013). Through isolating the cluster cells and performing gene expression analyses, we identified that they expressed a vast array of growth factors, chemokines and cytokines including members of the TGF, FGF and PDGF families of growth factors among many others. These cells could therefore act as signalling centres, likely changing the microenvironment and facilitating tumorigenesis (Andoniadou et al. 2012, 2013). An observation that was indicative of the potential of these cluster cells was that actively proliferating cells, as marked by immunofluorescence of Ki67, were readily detected in close proximity to the cell clusters in both mouse and human ACP (Gaston-Massuet et al. 2011). Several of the identified cytokines and growth factors have been shown to play a role in normal pituitary physiology as well as in pituitary adenomas (Arzt et al. 1999, 2009; Graciarena et al. 2004). Future work aims to reveal the 
mechanisms whereby cell clusters may induce paracrine cell transformation and promote tumour growth as well as the cell of origin of the ACP tumour mass. Taken together our data reveal that pituitary gland stem cells have the potential to contribute to tumorigenesis when mutated. In the case of ACP, they can instigate tumour formation in a non-cell autonomous manner, but this does not preclude the possibility of them acting as CSCs in other tumours.

Further research will better characterise PCS to reveal their defining features and potential as well as the mechanisms that regulate their activities, which can only enhance our ability to understand their possible role in disease and future regenerative medicine approaches, leading to more effective prognoses and treatments.

Open Access This chapter is distributed under the terms of the Creative Commons Attribution 4.0 International License (http://creativecommons.org/licenses/by/4.0/), which permits use, duplication, adaptation, distribution and reproduction in any medium or format, as long as you give appropriate credit to the original author(s) and the source, a link is provided to the Creative Commons license and any changes made are indicated.

The images or other third party material in this chapter are included in the work's Creative Commons license, unless indicated otherwise in the credit line; if such material is not included in the work's Creative Commons license and the respective action is not permitted by statutory regulation, users will need to obtain permission from the license holder to duplicate, adapt or reproduce the material.

\section{References}

Andoniadou CL, Gaston-Massuet C, Reddy R, Schneider RP, Blasco MA, Le Tissier P, Jacques TS, Pevny LH, Dattani MT, Martinez-Barbera JP (2012) ntification of novel pathways involved in the pathogenesis of human adamantinomatous craniopharyngioma. Acta Neuropathol 124: 259-271

Andoniadou CL, Matsushima D, Mousavy Gharavy SN, Signore M, Mackintosh AI, Schaeffer M, Gaston-Massuet C, Mollard P, Jacques TS, Le Tissier P, Dattani MT, Pevny LH, MartinezBarbera JP (2013) Sox2(+) stem/progenitor cells in the adult mouse pituitary support organ homeostasis and have tumor-inducing potential. Cell Stem Cell 13:433-445

Arnold K, Sarkar A, Yram MA, Polo JM, Bronson R, Sengupta S, Seandel M, Geijsen N, Hochedlinger K (2011) Sox2(+) adult stem and progenitor cells are important for tissue regeneration and survival of mice. Cell Stem Cell 9:317-329

Arzt E, Pereda MP, Castro CP, Pagotto U, Renner U, Stalla GK (1999) Pathophysiological role of the cytokine network in the anterior pituitary gland. Front Neuroendocrinol 20:71-95

Arzt E, Chesnokova V, Stalla GK, Melmed S (2009) Pituitary adenoma growth: a model for cellular senescence and cytokine action. Cell Cycle 8:677-678

Barker N, Ridgway RA, van Es JH, van de Wetering M, Begthel H, van den Born M, Danenberg E, Clarke AR, Sansom OJ, Clevers H (2009) Crypt stem cells as the cells-of-origin of intestinal cancer. Nature 457:608-611

Buslei R, Nolde M, Hofmann B, Meissner S, Eyupoglu IY, Siebzehnrubl F, Hahnen E, Kreutzer J, Fahlbusch R (2005) Common mutations of beta-catenin in adamantinomatous craniopharyngiomas but not in other tumours originating from the sellar region. Acta Neuropathol 109:589-597 
Buslei R, Holsken A, Hofmann B, Kreutzer J, Siebzehnrubl F, Hans V, Oppel F, Buchfelder M, Fahlbusch R, Blümcke I (2007) Nuclear beta-catenin accumulation associates with epithelial morphogenesis in craniopharyngiomas. Acta Neuropathol 113:585-590

Chen J, Hersmus N, Van Duppen V, Van Duppen V, Caesens P, Denef C, Vankelecom H (2005) The adult pituitary contains a cell population displaying stem/progenitor cell and early embryonic characteristics. Endocrinology 146:3985-3998

Chen J, Crabbe A, Van Duppen V, Vankelecom H (2006) The notch signaling system is present in the postnatal pituitary: marked expression and regulatory activity in the newly discovered side population. Mol Endocrinol 20:3293-3307

Chen J, Gremeaux L, Fu Q, Liekens D, Van Laere S, Vankelecom H (2009) Pituitary progenitor cells tracked down by side population dissection. Stem Cells 27:1182-1195

Chen M, Kato T, Higuchi M, Yoshida S, Yako H, Kanno N, Kato Y (2013) Coxsackievirus and adenovirus receptor-positive cells compose the putative stem/progenitor cell niches in the marginal cell layer and parenchyma of the rat anterior pituitary. Cell Tissue Res 354:823-836

Chen L, Ye H, Wang X, Tang X, Mao Y, Zhao Y, Wu Z, Mao XO, Xie L, Jin K, Yao Y (2014) Evidence of brain tumor stem progenitor-like cells with low proliferative capacity in human benign pituitary adenoma. Cancer Lett 349:61-66

Clevers H (2011) The cancer stem cell: premises, promises and challenges. Nat Med 17:313-319

Donangelo I, Ren SG, Eigler T, Svendsen C, Melmed S (2014) Sca1(+) murine pituitary adenoma cells show tumor-growth advantage. Endocr Relat Cancer 21:203-216

Drouin J (2016) Epigenetic mechanisms of pituitary cell fate specification. In: Pfaff D, Christen Y (eds) Stem cells in neuroendocrinology. Springer, Heidelberg

Fauquier T, Rizzoti K, Dattani M, Lovell-Badge R, Robinson IC (2008) SOX2-expressing progenitor cells generate all of the major cell types in the adult mouse pituitary gland. Proc Natl Acad Sci U S A 105:2907-2912

Garcia-Lavandeira M, Quereda V, Flores I, Saez C, Diaz-Rodriguez E, Japon MA, Ryan AK, Blasco MA, Dieguez C, Malumbres M, Alvarez CV (2009) A GRFa2/Prop1/stem (GPS) cell niche in the pituitary. PLoS One 4, e4815

Gaston-Massuet C, Andoniadou CL, Signore M, Jayakody SA, Charolidi N, Kyeyune R, Vernay B, Jacques TS, Taketo MM, Le Tissier P, Dattani MT, Martinez-Barbera JP (2011) Increased Wingless (Wnt) signaling in pituitary progenitor/stem cells gives rise to pituitary tumors in mice and humans. Proc Natl Acad Sci U S A 108:11482-11487

Gleiberman AS, Michurina T, Encinas JM, Roig JL, Krasnov P, Balordi F, Fishell G, Rosenfeld MG, Enikolopov G (2008) Genetic approaches identify adult pituitary stem cells. Proc Natl Acad Sci U S A 105:6332-6337

Graciarena M, Carbia-Nagashima A, Onofri C, Perez-Castro C, Giacomini D, Renner U, Stalla GK, Artz E (2004) Involvement of the gp130 cytokine transducer in MtT/S pituitary somatotroph tumour development in an autocrine-paracrine model. Eur J Endocrinol 151:595-604

Gremeaux L, Fu Q, Chen J, Vankelekom H (2012) Activated phenotype of the pituitary stem/progenitor cell compartment during the early-postnatal maturation phase of the gland. Stem Cells Dev 21:801-813

Higuchi M, Yoshida S, Ueharu H, Chen M, Kato T, Kato Y (2014) PRRX1 and PRRX2 distinctively participate in pituitary organogenesis and a cell-supply system. Cell Tissue Res 357:323-335

Hofmann BM, Kreutzer J, Saeger W, Buchfelder M, Blümcke I, Fahlbusch R, Buslei R (2006) Nuclear beta-catenin accumulation as reliable marker for the differentiation between cystic craniopharyngiomas and rathke cleft cysts: a clinico-pathologic approach. Am J Surg Pathol 30:1595-1603

Hosoyama T, Nishijo K, Garcia MM, Schaffer BS, Ohshima-Hosoyama S, Prajapati SI, Davis MD, Grant WF, Scheithauer BW, Marks DL, Rubin BP, Keller C (2010) A postnatal Pax7 progenitor gives rise to pituitary adenomas. Genes Cancer 1:388-402

Lepore DA, Roeszler K, Wagner J, Ross SA, Bauer K, Thomas PQ (2005) Identification and enrichment of colony-forming cells from the adult murine pituitary. Exp Cell Res 308:166-176 
Lloyd RV, Hardin H, Montemayor-Garcia C, Rotondo F, Syro LV, Horvath E, Kovacs K (2013) Stem cells and cancer stem-like cells in endocrine tissues. Endocr Pathol 24:1-10

Martinez-Barbera JP (2015) Molecular and cellular pathogenesis of adamantinomatous craniopharyngioma. Neuropathol Appl Neurobiol 41:721-732

Mertens FM, Gremeaux L, Chen J et al (2015) Pituitary tumors contain a side population with tumor stem cell-associated characteristics. Endocr Relat Cancer 22:481-504

Muller HL (2013) Paediatrics: surgical strategy and quality of life in craniopharyngioma. Nat Rev Endocrinol 9:447-449

Muller HL (2014) Craniopharyngioma. Endocr Rev 35(3):513-43. doi:10.1210/er.2013-1115

Orciani M, Davis S, Appolloni G et al (2015) Isolation and characterization of progenitor mesenchymal cells in human pituitary tumors. Cancer Gene Ther 22:9-16

Rizzoti K (2010) Adult pituitary progenitors/stem cells: from in vitro characterization to in vivo function. Eur J Neurosci 32:2053-2062

Rizzoti K, Akiyama H, Lovell-Badge R (2013) Mobilized adult pituitary stem cells contribute to endocrine regeneration in response to physiological demand. Cell Stem Cell 13:419-432

Valent P, Bonnet D, De Maria R, Lapidot T, Copland M, Melo JV, Chomienne C, Ishikawa F, Schuringa JJ, Stassi G, Huntly B, Herrmann H, Soulier J, Roesch A, Schuurhuis GJ, Wöhrer S, Arock M, Zuber J, Cerny-Reiterer S, Johnsen HE, Andreeff M, Eaves C (2012) Cancer stem cell definitions and terminology: the devil is in the details. Nat Rev Cancer 12:767-775

van Rijn SJ, Gremeaux L, Riemers FM, Brinkhof B, Vankelecom H, Penning LC, Meij BP (2012) Identification and characterisation of side population cells in the canine pituitary gland. Vet $\mathrm{J}$ 192:476-482

van Rijn SJ, Tryfonidou MA, Hanson JM, Penning LC, Meij BP (2013) Stem cells in the canine pituitary gland and in pituitary adenomas. Vet Quart 33:217-224

Vankelecom H (2010) Pituitary stem/progenitor cells: embryonic players in the adult gland? Eur J Neurosci 32:2063-2081

Vila-Porcile E (1972) The network of the folliculo-stellate cells and the follicles of the adenohypophysis in the rat (pars distalis). Z Zellforsch Mikrosk Ana 129:328-369

Xu Q, Yuan X, Tunici P, Liu G, Fan X, Xu M, Hu J, Hwang JY, Farkas DL, Black KL, Yu JS (2009) Isolation of tumour stem-like cells from benign tumours. Br J Cancer 101:303-311

Yoshida S, Kato T, Susa T, Cai LY, Nakayama M, Kato Y (2009) PROP1 coexists with SOX2 and induces PIT1-commitment cells. Biochem Biophys Res Commun 385:11-15

Yoshida S, Kato T, Yako H, Susa T, Cai LY, Osuna M, Inoue K, Kato Y (2011) Significant quantitative and qualitative transition in pituitary stem / progenitor cells occurs during the postnatal development of the rat anterior pituitary. J Neuroendocrinol 23:933-943

Yoshida S, Kato T, Higuchi M, Ueharu H, Nishimura N, Kato Y (2015) Localization of juxtacrine factor ephrin-B2 in pituitary stem/progenitor cell niches throughout life. Cell Tissue Res 359: $755-766$

Yunoue S, Arita K, Kawano H, Uchida H, Tokimura H, Hirano H (2011) Identification of CD133+ cells in pituitary adenomas. Neuroendocrinology 94:302-312

Zhu L, Gibson P, Currle DS, Tong Y, Richardson RJ, Bayazitov IT, Poppleton H, Zakharenko S, Ellison DW, Gilbertson RJ (2009) Prominin 1 marks intestinal stem cells that are susceptible to neoplastic transformation. Nature 457:603-607 